Pesq. Vet. Bras. 36(6):559-563, junho 2016 DOI: $10.1590 / \mathrm{S} 0100-736 \mathrm{X} 2016000600016$

\title{
Electrocardiographic exam in female spotted pacas (Cuniculus paca) ${ }^{1}$
}

\author{
Ricardo A.R. Uscategui², Vívian T. Almeida ${ }^{3}$, Aline E. Kawanami ${ }^{4}$, Wilmer A.Z. \\ Restan $^{2}$, Felipe F.P.C. Barros ${ }^{2}$, Marcus A.R. Feliciano ${ }^{3 *}$, Márcia R.F. Machado ${ }^{5}$ \\ and Wilter R.R. Vicentte ${ }^{3}$
}

\begin{abstract}
Uscategui R.A.R., Almeida V.T., Kawanami A.E., Restan W.A.Z., Barros F.F.P.C., Feliciano M.A.R., Machado M.R.F. \& Vicente W.R.R. 2016. Electrocardiographic exam in female spotted pacas (Cuniculus paca). Pesquisa Veterinária Brasileira 36(6):559-563. Departamento de Medicina Veterinária Preventiva e Reprodução Animal, Faculdade de Ciências Agrárias e Veterinárias, Universidade Estadual Paulista, Jaboticabal, Via de acesso Prof. Paulo Donato Castellane s/n, Jaboticabal, São Paulo, SP 14884-900, Brazil. E-mail: marcusfeliciano@yahoo.com.br

Considering the limited physiological information available on neotropical rodents and the importance of this information for pathophysiological and conservation studies of these species, the aim of this study was to evaluate the cardiac electric physiology of healthy captivity spotted pacas (Cuniculus paca) under chemical restraint, due to wild nature of these animals. Eleven adult female pacas were evaluated by blood count and biochemical dosage to rule out any associate disease. Each animal was evaluated in three periods every 15 days. After chemical restraint with intramuscular midazolam $0.5 \mathrm{mg} / \mathrm{kg}$ and ketamine $25 \mathrm{mg} / \mathrm{kg}$, animals were subjected to a computerized electrocardiogram, where bipolar (DI, DII and DIII) and augmented unipolar leads (aVR, aVL, aVF) were obtained. Descriptive statistics were calculated for each parameter and built the confidence interval (CI) at significance level of $95 \%$. The electrocardiographic examination was performed without difficult. ECG tracing in DII represents a QRS complex with positive polarity, preceded by a P wave of the same polarity and proceeded by $\mathrm{T}$ wave of variable polarity. Heart rate mean was $150 \pm 17 \mathrm{bpm}$, and cardiac electrical axis $33.4 \pm 21.9^{\circ}$. All animals showed sinusal rhythm. The ECG recording technique associated with chemical restraint was well tolerated, allowing quick acquisition of reliable ECG tracings with high repeatability, which produced sufficient results to determine the heart rhythm and suggest measures of ECG complexes duration and amplitude.
\end{abstract}

INDEX TERMS: Electrocardiographic exam, paca, Cuniculus paca, anesthesia, captive, cardiology, rodents, chemical restraint.

\footnotetext{
${ }^{1}$ Received on June 16, 2015

Accepted for publication on February 22, 2016.

${ }^{2}$ Departamento de Clínica e Cirurgia Veterinária, Faculdade de Ciências Agrárias e Veterinárias (FCAV), Universidade Estadual Paulista (Unesp), Jaboticabal, Via de acesso Prof. Paulo Donato Castellane s/n, Jaboticabal, SP 14884-900, Brazil.

${ }^{3}$ Departamento de Medicina Veterinária Preventiva e Reprodução Animal, FCAV-Unesp, Via de acesso Prof. Paulo Donato Castellane s/n, Jaboticabal, SP 14884-900, Brazil. *Corresponding author: marcusfeliciano@ yahoo.com.br

${ }^{4}$ Departamento de Patologia Veterinária, FCAV-Unesp, Via de acesso Prof. Paulo Donato Castellane s/n, Jaboticabal, SP 14884-900, Brazil.

${ }^{5}$ Departamento de Morfologia e Fisiologia Animal, FCAV-Unesp, Via de acesso Prof. Paulo Donato Castellane s/n, Jaboticabal, SP 14884-900, Brazil.
}

RESUMO.- [Exame eletrocardiográfico em pacas fêmeas (Cuniculus paca).] Considerando a limitada informação sobre a fisiologia cardíaca em roedores neotropicais e a importância desta informação para estudos fisiopatológicos e de conservação desta espécie, objetivou-se com este estudo avaliar a atividade elétrica cardíaca de pacas saudáveis mantidas em cativeiro, sob restrição química, devido à natureza selvagem destes animais. Onze fêmeas adultas foram avaliadas clinicamente e por meio do hemograma e testes bioquímicos no intuito de descartar qualquer co-morbidade associada. Cada animal foi submetido a três períodos experimentais a cada 15 dias. Após a restrição química com 
$25 \mathrm{mg} / \mathrm{kg}$ de cetamina e $0,5 \mathrm{mg} / \mathrm{kg}$ de midazolam pela via intramuscular, os animais eram submetidos a eletrocardiografia (ECG) computadorizada, aonde as derivações bipolares (DI, DII E DIII) e unipolares aumentadas (aVR, aVL, aVF) foram obtidas. A estatística descritiva foi calculada para cada parâmetro e o intervalo de confiança (CI), construído a um nível de significância de 95\%. 0 exame eletrocardiográfico foi realizado sem dificuldade. 0 traçado eletrocardiográfico em DII apresentou QRS com polaridade positiva, precedido por onda $\mathrm{P}$ da mesma polaridade e seguida por onda T de polaridade variável. A frequência cardíaca média foi de $150 \pm 17 \mathrm{bpm}$ e o eixo elétrico cardíaco de $33.4 \pm 21.9^{\circ}$. Todos os animais mostraram ritmo sinusal. A técnica eletrocardiográfica associada com restrição química foi bem tolerada permitindo a pratica aquisição de traçados de confiança e alta reprodutibilidade, que produziram resultados suficientes para determinar o ritmo cardíaco e sugerir medidas de duração e amplitude dos complexos de ECG.

TERMOS DE INDEXAÇÃO: Eletrocardiografia, paca, Cuniculus paca, anestesia, cativeiro, cardiologia, roedores, restrição química.

\section{INTRODUCTION}

Cuniculus paca that is the second largest rodent in South America (Matamoros 1982, Silva 1984), can weigh up to 14 $\mathrm{kg}$ (Matamoros 1982) and have an average life of 10 years (Lange \& Schmidt 2006). The indiscriminate hunting has placed it as an endangered specie (Chiarello et al. 2008). In order to preserve this animal, protected areas and commercial breeding were implanted (Lourenço et al. 2008), and studies to obtain biological data have been stimulated, especially reproductive characteristics, health indicators and nutrition studies (Berllago \& Cerqueira 1994, Redford 1997). Some clinical normal indicators have been established for spotted pacas (Reis et al. 2008, Feliciano et al. 2014), however only one postmortem study of cardiovascular morphology was published (Avila et al. 2010).

Among evaluation forms of cardiac system, the electrocardiographic (ECG) exam is a cheap diagnostic test, noninvasive, able to determine the cardiac rhythm and heart rate (Hanton \& Rabemampianina 2006, Scheer et al. 2010). However, reference values have not been established for many of the wild species and the lack of information in the literature limits the standardization for the cardiac function studies, capable to indicate cardiovascular changes in these species (Stępien 1999, Gardne et al. 2007, Estrada et al. 2009).

Considering the limited physiological information available in neotropical rodents and the importance of this information for pathophysiological and conservation studies of these species, the aim of this study was evaluate the cardiac electric physiology of healthy captive spotted pacas under chemical restraint, due to the wild nature of these animals.

\section{MATERIALS AND METHODS}

Eleven adult female pacas (Cuniculus paca Linnaeus, 1766), weighing $9.2 \pm 0.9 \mathrm{~kg}$ were used in this study. Each animal was submitted to experimental protocol every 15 days ( 3 times). Previously clinical evaluation, blood count and biochemical profile dosage (serum urea, creatinine and alanine aminotransferase - ALT) were made for all animals to rule out any associated disease. The study was approved by the Ethics Committee on Animal Use, process 027420/11, Unesp/Jaboticabal.

The pacas were kept adapted in their habits enclosures, getting food (dry rodents food, fruits and vegetables) and water ad libitum. Animals were no fasted, due to the physiological characteristics of the specie. Capture to physical restraint was made with hand net and the chemical restraint was performed using midazolam $0.5 \mathrm{mg} / \mathrm{kg}$ (Dormonid $^{\circledR}$, Roche, Sao Paulo, Brazil) and ketamine $25 \mathrm{mg} / \mathrm{kg}$ (Dopalen ${ }^{\circledR}$, Sespo Division Vetbrands Saúde Animal, São Paulo, Brazil) by intramuscular route (IM). Once immobilization was achieved, the animals were transferred to the operating room of the Veterinary Hospital "Governador Laudo Natel" Obstetric Service, where the electrocardiographic exam and further laparoscopic reproductive evaluation were performed.

For ECG exam, the animals were positioned in supine recumbency and the alligator type electrodes with gel (to ensure direct contact with the patient) were placed on the thoracic limbs above olecranon and on the hind limbs above patella (Fig.1). With a computerized electrocardiograph (ECG-PC version $2.27^{\circledR}$, TEB ${ }^{\circledR}$, São Paulo, Brazil) bipolar (DI, DII and DIII), and augmented unipolar leads (aVR, aVL and aVF) were obtained, at speed recording of $50 \mathrm{~mm} / \mathrm{s}$ and voltage calibration of $1 \mathrm{~cm} / \mathrm{mV}$. Three-minute intervals were recorded for later analysis. Using DII lead, cardiac rhythm characteristics, hearth rate (HR in beats per minute - bpm), cardiac electrical axis, duration in seconds (s) and/or amplitude in millivolts (mV) of the P wave (Ps and PmV), R wave (RmV), PR interval (PRs), QRS complex (QRSs), QT interval (QT) and T wave (TmV) were evaluated, according to Tilley suggestions (1992).

Statistical analysis was performed with R-software ${ }^{\circledR}$ (R Foundation for Statistical Computing, Vienna, Austria). Descriptive statistics were calculated for each parameter and built the confidence interval (CI) at significance level of $95 \%$.

\section{RESULTS}

Using the above described ECG exam method, the electrocardiographic tracing was obtained without significant artifacts (Figure 2) and all values obtained of analyzed parameters for the P-QRS-T deflections have been detailed in Table 1. Heart rate oscillated between 115 and $197 \mathrm{bpm}$, mean $150 \pm 17 \mathrm{bpm}$. All animas showed sinusal rhythm. Cardiac electrical axis ranged widely between -19 and $82^{\circ}$ and mean $33.4 \pm 21.9^{\circ}$. A ventricular extra-systole (VPC) isolated was recorded in one animal, without clinical significance.

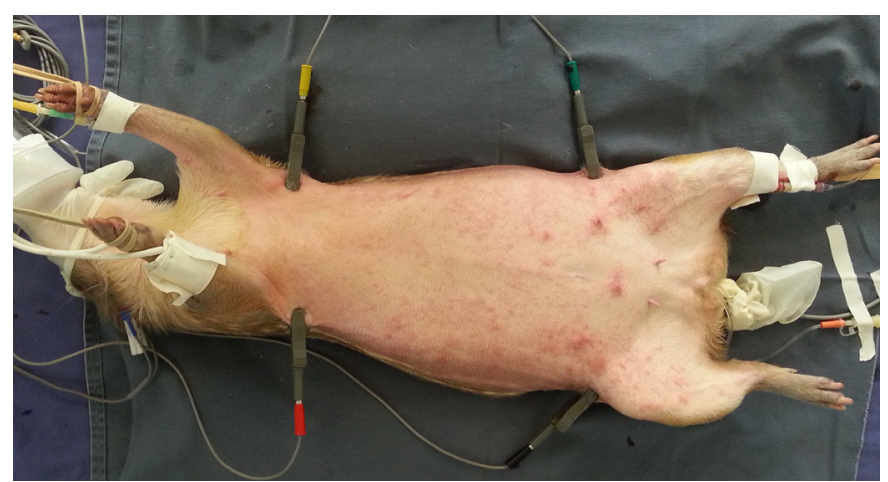

Fig. 1. Electrodes positioned in chemical restraint Cuniculus paca to perform electrocardiography exam. 


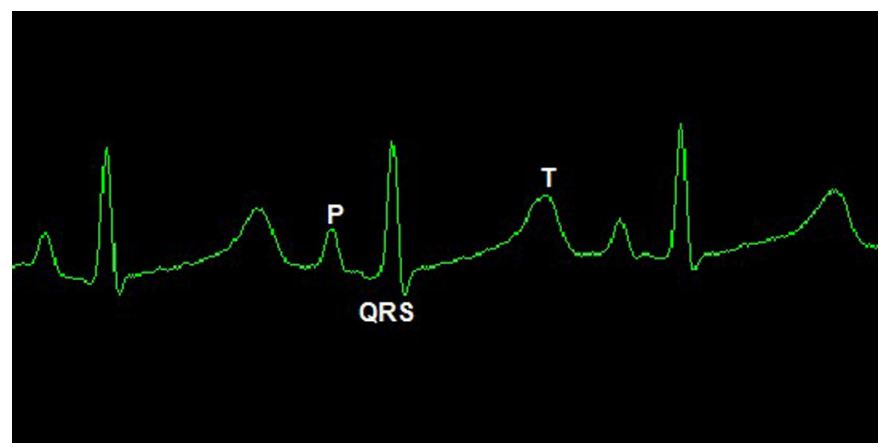

Fig.2. DII lead electrocardiography tracing in chemical restraint Cuniculus paca and its respective waves.

Table 1. Healthy chemical restraint females Cuniculus paca electrocardiographic parameters (mean \pm standard error), range, and $95 \%$ Confidence interval $(95 \% \mathrm{CI})$ in derivation DII.

\begin{tabular}{lccc}
\hline Parameter & Media \pm SE & $95 \%$ IC & Range \\
\hline Heart rate & $150 \pm 2.81$ & $144-156$ & $115-197$ \\
P wave height $(\mathrm{mV})$ & $0.14 \pm 0.04$ & $0.13-0.15$ & $0.07-0.19$ \\
P wave width (s) & $0.0514 \pm 0.0006$ & $0.0502-0.0527$ & $0.0397-0.0590$ \\
P-R Interval (s) & $0.1024 \pm 0.0015$ & $0.0994-0.1055$ & $0.0820-0.1200$ \\
R wave height (mV) & $0.49 \pm 0.18$ & $0.43-0.55$ & $0.12-0.86$ \\
QRS width (s) & $0.0588 \pm 0.0008$ & $0.0571-0.0605$ & $0.0443-0.0680$ \\
Q-T Interval (s) & $0.2540 \pm 0.0065$ & $0.2407-0.2674$ & $0.1900-0.3490$ \\
T wave (mV) & $0.14 \pm 0.013$ & $0.115-0.167$ & $0-0.3$ \\
Electrical axis $\left({ }^{\circ}\right)$ & $33.38 \pm 3.6$ & $25.98-40.78$ & $-19-82$
\end{tabular}

$(\mathrm{ms})=$ milliseconds; $(\mathrm{mV})=$ millivolts.

The ECG tracing of spotted pacas in DII lead allowed better recognition of waves represents a QRS complex with positive polarity (with a little negative $Q$ and $S$ waves) , preceded by a $\mathrm{P}$ wave of the same polarity and proceeded by $\mathrm{T}$ wave positive in $73 \%$ of patients and negative in remaining (Figure 2). Most P, R and T deflections were positive in D1, D2, D3 and aVF leads and negative in aVR, however the tracing in aVL presented variable polarities small deflections.

\section{DISCUSSION}

Electrocardiography is a non-invasive cardiac diagnostic tool used to record electric activity of the heart in humans and animals, providing information about electrical characteristics of cells and cardiac tissues. Therefore electrocardiography has been used routinely in human and veterinary medicine for cardiac evaluation (Varshney 2013). In pacas, this is the first study that provides information about heart physiology, aimed to report unpublished patterns of this assessment for the specie. However, it is important to remember that due to the wild nature of this specie, their handling and ECG evaluation should be done under chemical restraint. The drugs used for this restriction may have direct effects on cardiac function and can lead to changes in cardiac frequency and rhythm. For normal parameter studies, recognition of these alterations is very important. Ketamine is a dissociative anesthetic widely used in veterinary medicine (Fantoni 2002, Joslin 2003), with sympathetic mediated cardiovascular effect, evidenced by cardiac output, blood pressure, heart rate, and oxygen consumption increase (Wright 1982). Midazolam is a benzodiazepine sedative with limited effects on cardiovascular system, used in ketamine association to produce chemical restraint reducing the anesthetic dose and promoting muscle relaxation (Hall et al. 2014). This anesthetic protocol can lead to increased heart rate, as reported by Szabuniewicz et al. (1978) in capybaras.

Heart rate obtained in the studied pacas was similar to described in cats, dogs, maned wolves, capybaras and cheetahs (Szabuniew et al. 1978, Tilley 1992, Martin 2002, Schumacher et al. 2003, Estrada et al. 2009) higher than in Leopards (Oda et al. 2009) and lower than in brazilian agouti (Diniz et al. 2013). Although the capybara and brazilian agouti are phylogenetically closest to the paca (Ávila et al. 2010), the heart rate of these species has a moderate variation. The mean values reported were $130 \mathrm{bpm}$ in capybaras under chemical restraint (Szabuniew et al. 1978), 182 bpm in Brazilian agouti under physical restraint (Diniz et al. 2013) and $150 \mathrm{bpm}$ in this study of spotted pacas. These differences can be attributed to the animals' size (40kg, $2.3 \mathrm{~kg}$ and $9 \mathrm{~kg}$, respectively), since the body mass is inversely proportional to heart rate (Schmidt-Nielsen 1999).

The ECG tracing characteristics of spotted pacas in DII lead was similar to described for brazilian agouti, capybara, dogs, cats, ferrets, leopards, maned wolves, cheetahs and capuchin monkey (Szabuniewicz et al. 1978, Martin 2002, Tilley \& Goodwin 2002, Schumacher et al. 2003, Estrada et al. 2009, Oda et al. 2009, Dudás Györki et al. 2011, Larsson et al. 2012, Diniz et al. 2013), this ECG configuration indicate that the force of ventricular depolarisation spreaded principally to caudal and left side in front plane, due to positive R wave in DI, DII, DII and aVF, negative in aVR and small and variable in aVL leads, similar to described in ferrets (Dudás Györki et al. 2011). Due to the DII lead characteristics this is considered the most widely used derivation for the rhythm, frequency, configuration, amplitude, and duration, cardiac waves analysis (Hurst \& Meyerbur 1968), for this reason this derivation was presented as standard. Simultaneous additional leads monitoring is still important to arrhythmias diagnosis and monitoring.

The $\mathrm{P}$ wave duration, $\mathrm{PR}$, and QT intervals in pacas under chemical restraint were similar to that reported for capybaras (Szabuniewicz et al. 1978) and other wild mammals using a similar restraint protocol (Schumacher et al. 2003, Estrada et al. 2009, Oda et al. 2009), but were slightly larger than in Brazilian agouti, rabbits, ferrets and dogs under physical restraint (Szabuniew et al. 1971, Tilley \& Goodwin 2002, Dudás Györki et al. 2011, Diniz et al. 2013). Nevertheless, the $P$ wave amplitude was similar to that found in non-anesthetized ferrets, Brazilian agouti and chemical restrained cheetahs (Schumacher et al. 2003, Dudás-Györki et al. 2011, Diniz et al. 2013). This wave duration and amplitude represent the atrial conduction (Tilley \& Goodwin 2002) and the length increase observed in these animals and other mammal species under chemical restraint, it may be due to ketamine administration. Since this drug causes slight delay in electrical atrial conduction (Souza et al. 2002), probably as a result of pre and afterload increase (Nunes et al. 1997). The PR and QT intervals are considered inversely proportional to heart rate (Tilley 
1992) and may be elevated in anesthetized animals as observed by Szabuniewicz et al. (1978) in capybaras, due to the positive Chrono-tropic effect of dissociative anesthetics described by Souza et al. (2002) in dogs.

The QRS complex duration values obtained in this study were similar to normal values of Brazilian agouti, capybaras, cheetahs, leopards and maned wolves (Szabuniew et al. 1978, Schumacher et al. 2003, Estrada et al. 2009, Oda et al. 2009, Diniz et al. 2013) and higher than those reported in small rodents (Szabuniew et al. 1971, Dudás-Györki et al. 2011) and dogs (Tilley 1992). Although the variation in these values may not be correlated with size or heart rate in these animals, the value obtained is considered normal when compared with other species. Without evidences of other electrocardiographic signs compatible with overload as occurs in dogs (increase in amplitude of the $\mathrm{R}$ wave or right direction of the cardiac axis). Some factors too may be involved in the electrical conduction delay, as ketamine administration reported in capybaras and dogs (Szabuniewicz et al. 1978, Souza et al. 2002), and diaphragm displacement by gastric food accumulation that changes the heart position as described by Silva et al. (2005) since these animals were not fasted.

In domestic animals, $\mathrm{T}$ wave amplitude should be approximately $25 \%$ of $\mathrm{R}$ wave (Martin 2002). This relation in pacas was approximately 28\%; this is lower than in Brazilian agouti and capybaras (Szabuniewicz et al. 1978, Diniz et al. 2013) and similar to ferrets (Dudás-Györki et al. 2011). The $R$ wave amplitude in these pacas it would be considered cardiac suppression in dogs, common in obesity (Tilley 1992). Therefore, these values are considered normal in these animals.

The heart electrical axis (HEA) is the main electrical current flow direction during ventricles depolarization (Hamlin et al. 1986). In the frontal plane of these pacas it was between $26^{\circ}$ and $41^{\circ}$ corresponding to the values reported by Szabuniewicz et al. $(1971,1978)$ and Dudás-Györki et al. (2011) in rabbits, capybaras and ferrets; however was different from reports in Brazilian agouti (Diniz et al. 2013). These variations can be explained by thoracic conformations differences between animals as described by Lord et al. (2010) and Tilley (1992).

The ECG tracings were obtained and evaluated without difficulties, demonstrating the reproducibility of the technique for further studies. Although pacas are considered wild animals, scientific interest in this species is growing in Brazil, demonstrating the great value of these results. The electrocardiographic parameters may be different in males and unanesthetized animals (Szabuniewicz et al. 1978, Diniz et al. 2013), considering these factors as study limitations, further studies evaluating these parameters in males, and unanesthetized pacas are recommended.

\section{CONCLUSION}

This was in our view the first study that assessed spotted pacas' heart by electrocardiography. The ECG recording technique associated with chemical restraint was well tolerated, allowing quick acquisition of reliable ECG tracings with high repeatability, which produced sufficient results to determine the heart rhythm and suggest measures of ECG complexes duration and amplitude. Further studies are needed to determine ECG normal parameters in this specie, considering the genre, state of conscience, and possible heart diseases.

Acknowledgements.- The authors would like to thank the National Council for Scientific and Technological Development (CNPq), Coordination for the Improvement of Personnel of Superior Level (CAPES) and the Foundation for Research Support of the State of São Paulo (FAPESP) for financial support. Also to Dr. Julio Carlos Canola radiology service boss, and to Veterinary Hospital "Governor Laudo Natel" FCAV-Unesp, Jaboticabal, for lending, equipment, infrastructure and staff. To Leandro Nassar Coutinho, Luciana Cristina Padilha Nakaghi, Victor José Correa Santos, Ricardo Perecin Nociti, Mariana Garcia Kako Rodriguez, Renata Sitta Gomes Mariano, and Roberta Martins Crivelaro, for their help in data collection. Also to the Morphology and Animal Physiology Department, for animals used in this experiment.

\section{REFERENCES}

Ávila B.H.P., Machado M.R.F. \& Oliveira F.S. 2010. Descrição anátomo-topográfica do coração da paca (Agouti paca). Acta Scient. Vet. 38(2):191-195.

Berllago H.G. \& Cerqueira R. 1994. Reproduction and growth of the opossum Monodelphis domestica (Mammalia: Didelphida) in Northeastern Brazil. J. Zool., Lond., 232:551-563.

Chiarello A.G, Aguiar L.M.S, Cerqueira R., Melo F.R, Rodrigues F.H.G \& Silva V.M.F. 2008. Mamíferos Ameaçados de Extinção no Brasil, p. 680-880. In: Machado A.B.M., Drummond G.M. \& Paglia A.P. (Eds), Livro Vermelho da Fauna Brasileira Ameaçada de Extinção. MMA Ministério do Meio Ambiente, Brasília, Fundação Biodiversitas, Belo Horizonte.

Diniz N.A., Silva Júnior J.R., Guerra P.C., Barreto-Júnior R.A., Almeida H.M., Freire L.D., Ambrósio C.E. \& Alves F.R. 2013. Electrocardiogram assessment in non-anaesthetized clinically healthy agouti (Dasyprocta primnolopha Wagler 1831). Pesq. Vet. Bras. 33:8-14.

Dudás-Györki Z., Szabó Z., Manczur F. \& Vörös K. 2011. Echocardiographic and electrocardiographic examination of clinically healthy, conscious ferrets. J. Small Anim. Pract. 52:18-25.

Estrada A.H., Gerlach T.J., Schmidt M.K., Siegal-Willott J.L., Adrienne L., Atkins A.L., Scott B., Citino S.B. \& Padilla L.R. 2009. Cardiac evaluation of clinically healthy captive maned wolves, Chrysocyon brachyurus. J. Zoo Wildl. Med. 40:478-486.

Fantoni D.T. 2002. Anestesia no cardiopata, p.294-320. In: Fantoni D.T. \& Cortopassi S.R.G. (Eds), Anestesia em Cães e Gatos. Roca, São Paulo.

Feliciano M.A.R., Barros F.F.P.C., Coutinho L.N., Brito M.B.S., Uscategui R.R., Santos V.J.C., Almeida V.T., Kawanami A.E., Nociti R.P., Machado M.R.F. \& Vicente W.R.R. 2014. Conventional and Doppler Abdominal Ultrasonography in pacas (Cuniculus paca). Acta Scient. Vet. 42:1235.

Gardne A., Thompson M.S., Fontenot D., Gibson N. \& Heard D.J. 2007. Radiographic evaluation of cardiac size in flying fox species (Pteropus rodricensis, P. hypomelanus and P. vampyrus). J. Zoo Wildl. Med. 38:192-200.

Hall L.W., Clarke K.W. \& Trim C.M. 2014. Veterinary Anaesthesia. 11th ed. Saunders Elsevier, London, p.135-137.

Hamlin R.L., Hren J. \& Sparrow P.V. 1986. Electrocardiographic evaluation of the healthy raccoon, Procyon lotor. Am. J. Vet. Res. 47:814-817.

Hanton G. \& Rabemampianina Y. 2006. The electrocardiogram of the Beagle dog: reference values and effect of sex, genetic strain, body position and heart rate. Lab. Anim. 40:123-136.

Hurst J.W. \& Myerburg R.J. 1968. Introduction to Electrocardiography. McGraw-Hill Book Co, New York, p.262-263.

Joslin J.O. 2003. Other primates excluding great apes, p.346-381. In: Fowler M.E. (Ed.), Zoo and Wild Animal Medicine. 5th ed. W.B. Saunders, Philadelphia, Pennsylvania.

Larsson M.H.M.A., Pellegrino A., Oliveira V.M.C, Prada C.S., Fedullo J.D. \& Larsson Junior C.E. 2012. Electrocardiographic parameters of captive Tufted Capuchins (Cebus apella) under chemical immobilization. J. Zoo Wildl. Med. 43(4):715-718. 
Lange R.R. \& Schmidt E.M.S. 2006. Rodentia - Roedores Silvestres (Capivara, Cutia, Paca, Ouriço), p.475-491. In: Cubas Z.S., Silva J.C.R. \& Catão-Dias J.L. (Eds), Tratado de Animais Selvagens: medicina veterinária. Roca, São Paulo.

Lord B., Boswood A. \& Petrie A. 2010. Electrocardiography of the normal domestic pet rabbit. Vet. Rec. 167:961-965.

Lourenço R.F.S., Dias R.S. \& Gomes A.P.A. 2008. Criação de paca (Agouti paca) como alternativa de diversificação de produção e renda em Minas Gerais. Anais 46ํㅡㄹ Congresso da Sociedade Brasileira de Economia, Administração e Sociologia Rural, Rio Branco, AC, p.1-20. (Resumo)

Matamoros Y. 1982. Notas sobre la biologia del tepezcuinte, Cuniculus paca Brisson (Rodentia: Dasyproctidae) en cautiverio. Brenesia 19/20:71-82.

Martin M. 2002. ECG interpretation in small animals: practical guidelines. In Practice 24:250-261.

Schmidt-Nielsen K. 1999. Fisiologia animal: adaptações e meio ambiente. $5^{\underline{a}}$ ed. Santos Livraria, São Paulo. 600p.

Nunes N., Camacho A.A., Kronka S.N. \& Costa J.L.O. 1997. Eletrocardiographic study of the anesthetic combination of ketamine and chlorpromazine HCL in felines. Braz. J. Vet. Res. Anim. Sci. 34:313-316.

Oda S.G.S., Yamat R.J., Fedullo J.D.L., Neto M.L. \& Larsson M.H.M. 2009. Standardization of some electrocardiographic parameters of captive leopard cats, Leopardus tigrinus. J. Zoo Wildl. Med. 40:414-420.

Redford K.H. 1997. Manejo e conservação de vida silvestre no Brasil, p.122. In: Redford K.H. (Ed.), A Floresta Vazia, Mamirauá, AM.

Reis A.C.G., Santana A.M., Fagliari J.J., Machado M.R.F., Ávila L.G. \& Maluta R.P. 2008. Hematologia e bioquimico sérico de pacas (Agouti paca Linnaeus, 1766), criadas em cativeiro. Anais da Oitava Conferência Sul-Americana de Medicina Veterinária, Rio de Janeiro, Brazil.

Scheer P., Svoboda P., Sepsi M., Janečková K. \& Doubek J. 2010. The electrocardiographic Holter monitoring in experimental veterinary practice. Physiol. Res. 1:59-64.
Schumacher J., Snyder P., Scott B., Citino S.B., Bennett R.A. \& Dvorak L.D. 2003. Radiographic and electrocardiographic evaluation of cardiac morphology and function in captive cheetahs Acinonyx jubatus. J. Zoo Wildl. Med. 34:357-363.

Silva F. 1984. Ordem Rodentia: mamíferos silvestres do Rio Grande do Sul. Fundação Zoobotânica do Rio Grande do Sul, Porto Alegre, p.171-209.

Silva E.M., Duarte D.P.F. \& Costa C.P. 2005. Electrocardiographic studies of the three-toed sloth, Bradypus variegatus. Braz. J. Med. Biol. Res. 38:1885-1888.

Souza A.P., Carareto R., Nunes N., Leite A.V. \& Paula D.P. 2002. Electrocardiography in dogs anesthetized with s-ketamine or ketamine. Ciência Rural 32(5):787-791.

Stepien R.L., Benson K.G. \& Forrest L.J. 1999. Radiographic measurement of cardiac size in normal ferrets. Vet. Radiol. Ultrasound 40:606-610.

Szabuniewicz M., Hightower D. \& Kyzar J.R. 1971. The Electrocardiogram, Vectorcardiogram and Spatiocardiogram in the Rabbit. Can. J. Comp. Med. 35(2):107-114.

Szabuniewicz J.M. \& Szabuniewicz M. 1978. The electrocardiogram of the Virginia opossum Didelphis virginiana. Zentralbl. Veterinärmed. 25:785-793.

Tilley L.P. 1992. Tables for determining the frontal plane mean electrical axis, p.443-447. In: Tilley L.P. (Ed.), Essentials of Canine and Feline Electrocardiography. 3rd ed. Lippincott Williams and Williams, Philadelphia.

Tilley L.P. \& Goodwin J.K. 2002. Manual de Cardiologia para Cães e Gatos. $3^{\text {a }}$ ed. Roca, São Paulo. 489p.

Varshney J.P. 2013. Applications of electrocardiography in physiological and clinical research. XXII Annual Conference of Society of Animal Physiologists of India and National Symposium on Physiological and Nutri-Genomic Interventions to Augment Food Security an Animal Welfare, November 19-21, 2013.

Wright M. 1982. Pharmacologic effects of ketamine and its use in veterinary medicine. J. Am. Vet. Med. Assoc. 180:1462-1471. 